\title{
Which Relationship between Gender Diversity, Intellectual Capital and Financial Performance?
}

\author{
Marco Giuliani ${ }^{1} \&$ Simone Poli ${ }^{1}$ \\ ${ }^{1}$ Department of Management, Università Politecnica delle Marche, Ancona, Italy \\ Correspondence: Simone Poli, Department of Management, Università Politecnica delle Marche, Piazzale R. \\ Martelli 8, 60121, Ancona, Italy. E-mail: s.poli@univpm.it
}

Received: June 24, 2019

Accepted: August 18, 2019

Online Published: September 5, 2019

doi:10.5539/ijbm.v14n10p101

URL: https://doi.org/10.5539/ijbm.v14n10p101

\begin{abstract}
Some would argue that gender diversity, both in ownership and in board of directors, can affect both financial performance and intellectual capital (IC) performance, and that the latter, in turn, can affect financial performance. This leads to hypothesise that IC performance can be a mediator in the relationship between gender diversity, in ownership or board of directors, and financial performance. As this hypothesis does not appear to have had an adequate investigation in literature, this paper aims to investigate if IC performance can be considered as a mediator in the relationship between gender diversity and financial performance. The test of this hypothesis is performed applying the multiple regression model suggested by Baron and Kenny (1986) to a sample of Italian small and medium-sized enterprises (SMEs). The study shows that gender diversity in ownership negatively impacts on financial performance, directly and indirectly, and that gender diversity in board of directors negatively impacts on financial performance, only indirectly. The indirect effects are due to the negative impact of gender diversity, both in ownership and in board of directors, on IC performance. IC performance plays the role of mediator in the relationship between gender diversity and financial performance. The mediating effect is partial regarding gender diversity in ownership. It is perfect concerning gender diversity in board of directors. This study contributes to the extant literature about the relationships between gender diversity, IC performance and financial performance by offering a systemic analysis of these three items that tend to be investigated separately.
\end{abstract}

Keywords: financial performance, intellectual capital performance, $\mathrm{VAIC}^{\mathrm{TM}}$, gender diversity, ownership, board of directors, mediation effect, Italian SMEs

\section{Introduction}

Some would argue that Intellectual Capital (IC) can be considered as one of the main levers to create value, i.e. by improving the IC performance, it is possible to improve the firm overall one (Dumay, 2012; Edvinsson \& Malone, 1997; Sveiby, 1997). This "grand theory" (Dumay, 2012) has stimulated the development of a plethora of studies regarding the linkages between IC performance and financial performance (Chen, Cheng, \& Hwang, 2005; Dumay, 2012; Maditinos, Chatzoudes, Tsairidis, \& Theriou, 2011). It has to be noticed that the extant analyses have shown that a relationship between IC performance and financial performance exists. As IC is not relevant per se but as a part of a wider organisational value creation process, some scholars have also started investigating the determinants of the IC performance as well as the items that, by interacting with IC, can improve the organisational performance. These studies have shown that, for example, the level of profitability, as well as the organizational risk-approach and the geographical localization of the plants, can influence the capacity of a firm to create and develop IC (El-Bannany, 2008; Giuliani, 2013; Giuliani \& Marasca, 2011; Mavridis, 2005; Meressa, 2016).

An aspect that is receiving increasing interest by both researchers and practitioners is gender diversity. It can be defined as the degree of heterogeneity of the members of a group or organisation considering their gender ( $\mathrm{Li}$ et al., 2016). It represents the most debated diversity issue as it is a way of representing female participation in economic activity and society in general (Campbell \& Mínguez-Vera, 2008). Previous studies have found that it is able to have an impact on several dimensions of the performance of a group or organisation, such as the financial and the social ones (Ali, Kulik, \& Metz, 2011; Bear, Rahman, \& Post, 2010; Campbell \& Mínguez-Vera, 2008; Carter, D'Souza, Simkins, \& Simpson, 2010; Dwyer, Richard, \& Chadwick, 2003; Fairlie 
\& Robb, 2009; Powell \& Ansic, 1997; Rao \& Tilt, 2016).

Starting from the assumption that the overall performance of the firm or some of its dimensions can be affected by gender diversity, some scholars have investigated the existence of a relationship between gender diversity and IC performance. In particular, they have analysed the effects of gender diversity in board of directors (Al-Musali \& Ismail, 2015; Der Zahn \& Mitchell, 2004; Saeed, Rasid, \& Basiruddin, 2014; Swartz \& Firer, 2005) and in ownership (Chiucchi, Giuliani, \& Poli, 2018b) on IC performance showing that a relationship between them seems to exist. Even if this research is still at an early stage, it seems possible to argue that gender diversity can affect both financial performance and IC performance and that the latter, in turn, can affect financial performance. This leads to the hypothesis that IC performance can be a mediator in the relationship between gender diversity and financial performance.

As this hypothesis does not appear to have had an adequate investigation in literature, the aim of this paper is to investigate whether IC performance can be considered as a mediator in the relationship between gender diversity and financial performance.

This hypothesis will be tested on a sample of Italian small- and medium-sized enterprises (SMEs). The focus on SMEs is due to several reasons. First, SMEs are particularly relevant in terms of number and economic incidence, both in Italy and, more in general, in Europe. Second, most of the extant studies on IC and gender diversity focus on large listed companies and overlook SMEs. Third, the study investigates gender diversity not only in the boards of directors but also in the ownership, and this requires that owners are only individuals, as it is typical in SMEs.

Gender diversity will be observed with reference both to the board of directors and to the owners. The focus on the board of directors is because the directors are the ones that manage IC and the firm and, for this reason, boards are the most frequent object of research in the gender diversity discourse. The focus on owners is because in SMEs the gender and the other qualities of owners can have great relevance, maybe even superior to the ones of the directors (Elizabeth \& Baines, 1998; Fairlie \& Robb, 2009; Johnsen \& McMahon, 2005; Watson \& Robinson, 2003). In other words, some argue that it is not only the board of directors but also the owners that have a relevant influence on the SME's performance (Abor \& Biekpe, 2007; Arosa, Iturralde, \& Maseda, 2010; Chu, 2009; Daily \& Dollinger, 1992). In addition, the effects of gender diversity in ownership in SMEs have been scarcely investigated (Carter, Anderson, \& Shaw, 2000; Cohen \& Kaimenakis, 2007; Johnsen \& McMahon, 2005; Neergaard, Shaw, \& Carter, 2005; Ngah \& Ibrahim, 2009; Orser, Riding, \& Manley, 2006; Shahveisi, Khairollahi, \& Alipour, 2016; Steenkamp \& Kashyap, 2010).

The paper proceeds as follows. In section 2, the main literature is reviewed, and the research hypotheses are developed. In section 3 , the research design and the sample selection are described. In section 4 , the empirical results are shown. In section 5, the findings are discussed, and the main contributions to the literature, the limitations of the study, and possible further research opportunities are highlighted.

\section{Literature Review and Development of Research Hypotheses}

\subsection{IC Performance and Financial Performance}

Numerous definitions of IC exist in literature. By way of example, it is possible to find IC defined adopting a static perspective or a more dynamic one. Concerning the former, IC can be considered as the system composed of all of the firm's intangibles (Meritum, 2002) or as the "sum" of knowledge-related items able to allow the company to have a competitive edge (Stewart, 1997). Adopting a dynamic perspective, IC can be defined as a system of knowledge flows (Mouritsen \& Larsen, 2005) or as the whole of connections and interactions between intangible resources (Chaminade \& Roberts, 2003). In all, IC can be considered as a resource or as a process (Arenas \& Lavanderos, 2008). Even if there is not a generally accepted definition, IC appears to be mainly understood as the system of intangibles (resources and related activities) that gives a firm a competitive edge.

IC is generally described as composed of three main elements, i.e. human capital, structural capital and relational capital (Edvinsson \& Malone, 1997; Meritum, 2002; Mouritsen, 2009; Stewart, 1997). The first component comprises tacit knowledge, know-how and competencies that are at the basis of the knowledge creation process and that guide the ability in decision-making and resource allocation. The second component comprises all those mechanisms and structures of the organisation that support employees in their quest for optimum IC performance. The third component is an asset that draws its value from the social relationships and networks among the organisation and its stakeholders, communities and/or society.

One of the "grand theories" (Dumay, 2012) that dominate the IC discourse is that IC performance drives the financial one (Dumay, 2012; Edvinsson \& Malone, 1997; Sveiby, 1997). This "grand theory" has stimulated the 
development of a plethora of studies regarding the links between IC performance, on the one hand, and organisational and financial performance, on the other hand. These studies have been developed with reference to different geographical contexts, such as UK (Pulic, 2000a; Zeghal \& Maaloul, 2010), Singapore (Pew Tan, Plowman, \& Hancock, 2007), Turkey (Ozturk \& Demirgunes, 2007), Pakistan (Makki \& Lodhi, 2008), Malaysia (Gan \& Saleh, 2008; Mojtahedi, 2013), Taiwan (Cheng, Lin, Hsiao, \& Lin, 2010), Spain (María Díez, Lizet Ochoa, Begona Prieto, \& Santidrián, 2010), Sweden (Graaf, 2013), Romania (Gruian, 2011), Nigeria and Australia (Clarke, Seng, \& Whiting, 2011), and also with reference to different industries, such as real estate, banking, manufacturing, service, IT, etc. (Nimtrakoon, 2015; Pitelli Britto, Monetti, \& da Rocha Lima Jr, 2014; Singh \& Narwal, 2015).

These studies tend to achieve similar conclusions. First, there is a significant link between IC performance and firm value, firm profitability and market ratios. IC seems to be more responsible for financial efficiency rather than physical capital. Third, the three IC components do not have the same role in influencing the IC performance: human capital performance tend to have a significant link with financial performance.

From a methodological strand, these investigations have been mainly developed with statistical analyses focused on large companies where the IC performance is considered as the independent variable and it is measured using the VAIC ${ }^{\mathrm{TM}}$ model (Chen, Cheng, \& Hwang, 2005; Dumay, 2012; Maditinos, Chatzoudes, Tsairidis, \& Theriou, 2011).

\subsection{Gender Diversity and Company Performance}

The interest in gender diversity in business can be related to several discourses, such as the recognition of female human resources as important sources of organizational competitive advantage (Rogelberg \& Rumery, 1996), the promulgation of equal opportunity laws that have pushed organisations to employ women in key roles (Ali, Kulik, \& Metz, 2011) and the promotion of political and social activities to support and spread gender equality over the years among leaders in business, government, and civil society (Kalev, Dobbin, \& Kelly, 2006).

This situation has encouraged several scholars to analyse the effects of gender diversity on the overall corporate performance and on its specific dimensions. In particular, some scholars have investigated the connections between gender diversity, mainly referred to boards and CEOs, and firm reputation (Bear, Rahman, \& Post, 2010), ethical business behaviour (Betz, O'Connell, \& Shepard, 1989), environmental practices (Li et al., 2016), competitive advantage (Kalleberg \& Leicht, 1991), innovation (Gry Agnete Alsos, Dr Elisabet Ljunggren, Agnete Alsos, Ljunggren, \& Hytti, 2013), entrepreneurship (Laure Humbert \& Drew, 2010), firm performance (Ali, Kulik, \& Metz, 2011; Campbell \& Mínguez-Vera, 2008; Carter, D'Souza, Simkins, \& Simpson, 2010; Elizabeth \& Baines, 1998), bank-firm relationships (Bellucci, Borisov, \& Zazzaro, 2010), risk behaviour (Byrnes, Miller, \& Schafer, 1999; Powell \& Ansic, 1997; Zinkhan \& Karande, 1991), decision making processes (Rogelberg \& Rumery, 1996), etc., achieving very different results and highlighting the need for more in depth investigation. In all, gender diversity appears to influence, in various ways, several dimensions of the firm overall performance, such as the social and the environmental ones.

Regarding the way how gender diversity can affect the firm overall performance, a review of the extant studies (Horwitz, 2005; Horwitz \& Horwitz, 2007), mainly focused on large firms, shows that two competing theories can explain the relationship between gender diversity and performance. According to the "similarity-attraction paradigm" (the first theory), homogeneous groups and organisations perform better than the heterogeneous ones because they tend to share the same language, approach, way of acting, etc. and consequently they are more productive. In detail, some scholars suggest that members of homogeneous groups and organisations are more likely to share the same opinions, to be more cooperative and less conflictual, to experience fewer emotional conflicts, and to develop less time consuming and more effective decision-making processes (Andreoni \& Vesterlund, 2001; Earley \& Mosakowski, 2000; Lau \& Murnighan, 1998; Tajfel \& Turner, 2004; Williams \& O'Reilly III, 1998). Conversely, according to the "cognitive resource diversity theory", diversity has a positive impact on performance because heterogeneous members of groups and organisations promote creativity, innovation, and problem-solving, hence generating more informed decisions (Brammer, Millington, \& Pavelin, 2007; Campbell \& Mínguez-Vera, 2008; Robinson \& Dechant, 1997; Smith, Smith, \& Verner, 2006).

To sum up, it is recognised that gender diversity influences the company performance, even if it is still debated if it is true that the more gender diversity, the better.

\subsection{Gender Diversity and IC Performance}

IC performance can be understood as one of the dimensions that concur to define the overall performance of a company. (Firer \& Mitchell Williams, 2003). Considering that gender diversity seems to be able to influence 
different dimensions of the overall performance of a company, some would argue that it is also able to influence IC performance. However, only a few studies have directly investigated this issue.

Chiucchi, Giuliani, and Poli (2018b) argue that IC performance is related to ownership gender diversity in a negative way, i.e. the higher the gender diversity, the lower the IC performance. In addition, they highlight that IC performance is negatively related to ownership structure size, i.e. the smaller the number of owners, the higher the IC performance. Moreover, they show that ownership structure size moderates the relationship between ownership gender diversity and IC performance. More precisely, ownership size emphasises the (negative) impact of gender diversity on IC performance.

Der Zahn and Mitchell (2004) investigate the association between the level of gender and ethnic diversity on the boards of directors of South African publicly listed firms and their degree of IC performance. Their study shows that the incidence of female and non-white directors is positively associated with IC performance. They also show that the designation of female directors as insiders negatively impacts on IC performance, while the designation of female and non-white directors as outsiders positively impacts on it.

Swartz and Firer (2005) examine the relationship between gender and ethnic diversity on board of directors and IC performance in South African public companies. Consistently with the previous study, the two scholars argue that the degree of diversity and IC performance are positively associated in a statistically significant way.

In summary, it seems that gender diversity and IC performance are associated, but the effects of gender diversity on IC performance are still unclear and need further investigations as the results achieved up to date are not converging (Al-Musali \& Ismail, 2015; Chiucchi, Giuliani, \& Poli, 2018b; Der Zahn \& Mitchell, 2004; Saeed, Rasid, \& Basiruddin, 2014; Swartz \& Firer, 2005).

\subsection{Research Hypotheses}

Even if the findings of the mentioned studies are mixed, it seems possible to argue that gender diversity can affect both financial performance and IC performance and that the latter, in turn, can affect financial performance. This idea leads to hypothesise that IC performance can be a mediator in the relationship between gender diversity and financial performance. Consequently, the research hypotheses being tested are the following:

$H_{1}$ : IC performance mediates the relationship between gender diversity in ownership and financial performance.

$\mathrm{H}_{2}$ : IC performance mediates the relationship between gender diversity in board of directors and financial performance.

\section{Research Design and Sample Selection}

In order to test the research hypotheses, the Baron and Kenny's (1986) testing mediation model is adopted.

This model is based on the estimation of three regression equations. First, IC performance (namely, the mediator) is regressed on gender diversity in ownership or board of directors (namely, the independent variable). Second, financial performance (namely, the dependent variable) is regressed on gender diversity in ownership or board of directors (namely, the independent variable). Third, financial performance (namely, the dependent variable) is regressed on both gender diversity in ownership or board of directors (namely, the independent variable) and IC performance (namely, the mediator).

According to the model used, a mediation effect exists if:

1) gender diversity in ownership or board of directors impacts on IC performance in the first equation;

2) gender diversity in ownership or board of directors impacts on financial performance in the second equation;

3) IC performance impacts on financial performance in the third equation;

4) the impact of gender diversity in ownership or board of directors on financial performance is less in the third equation than in the second one.

\subsection{The dependent variable (financial performance)}

Financial performance is measured in two different and alternative ways:

- $\quad$ return on equity (ROE), calculated as follows:

$$
\frac{N I_{n}}{\frac{S E_{n}+S E_{n-1}}{2}}
$$


- return on total assets (ROA), calculated as follows:

$$
\frac{N I_{n}}{\frac{T A_{n}+T A_{n-1}}{2}}
$$

where: $\mathrm{NI}$ is net income, $\mathrm{SE}$ is shareholder equity, $\mathrm{TA}$ is total assets, and $\mathrm{n}$ is the year of reference.

\subsection{The Mediator (IC Performance)}

The Value Added Intellectual Coefficient $\left(\right.$ VAIC $^{\mathrm{TM}}$ ) (Pulic, 2000b) is used to measure IC performance. Literature shows that it is a widely accepted indicator of IC performance in the academic and professional community (Bontis, Bart, Nazari, \& Herremans, 2007; Chen, Cheng, \& Hwang, 2005; El-Bannany, 2008; Firer \& Mitchell Williams, 2003; Mavridis, 2005; Pew Tan, Plowman, \& Hancock, 2007; Pulic, 2000b; Ståhle, Ståhle, \& Aho, 2011; Zéghal \& Maaloul, 2010). Some studies highlight the limitations of the VAIC ${ }^{\mathrm{TM}}$ (Iazzolino \& Laise, 2013; Maditinos, Chatzoudes, Tsairidis, \& Theriou, 2011; Ståhle, Ståhle, \& Aho, 2011) such as: 1) it is based on financial reports that reflect past strategies; 2) it is not able to reflect the synergies among its various components and the holistic aspect of IC; 3 ) it does not consider relational capital; 4) it considers human and structural capital only partially (e.g., it considers the annual salaries of the employees but not their knowledge, skills, motivation, experience, or training); 5) it treats IC and performance linearly. According to Iazzolino and Laise (2013), most of the criticism levelled at the VAIC ${ }^{\mathrm{TM}}$ is due to a misunderstanding and/or misuse of the model. It aims to measure how IC contributes to value creation and not aim to measure the value or stock of IC. Nevertheless, the $\mathrm{VAIC}^{\mathrm{TM}}$ has a great advantage in that it is directly drawn from the firm's management accounts, and therefore the data need for its calculation are practically guaranteed to be available under standard accounting rules.

The choice to use the VAIC ${ }^{\mathrm{TM}}$ model for this analysis is because it is widely used for empirical analyses and it is based on financial statements that are generally available for smaller companies: this allows to base the analysis on large samples and comparable data. Other IC measurements and reports, instead, are generally available only for larger companies, and they are generally not comparable (Chiucchi, Giuliani, \& Marasca, 2016; Giuliani, 2014; Giuliani, Chiucchi, \& Marasca, 2016).

Algebraically, $\mathrm{VAIC}^{\mathrm{TM}}$ is expressed as follows:

$$
V A I C^{T M}=\frac{\text { value added }}{\text { total cost for employees }}+\frac{\text { value added }- \text { total cost for employees }}{\text { value added }}+\frac{\text { value added }}{\text { total assets }- \text { intangible assets }}
$$

In the context of Italian private companies, value added is the sum of operating profit, total cost for employees, depreciation and amortisation, and provisions (Chiucchi, Giuliani \& Poli, 2018a; Chiucchi et al., 2018b).

\subsection{The Independent Variable (Gender Diversity in Ownership Or Board of Directors)}

Gender diversity in ownership and, alternatively, in board of directors is measured through the diversity index of Shannon (1948):

$$
-p_{\text {male }} \times \ln p_{\text {male }}-p_{\text {female }} \times \ln p_{\text {female }}
$$

Where $\mathrm{p}$ is the proportion of male (female) owners or members of the board of directors.

When the gender diversity in ownership is considered, $\mathrm{p}$ can be understood and calculated in different ways (Chiucchi, Giuliani, \& Poli, 2018a; Chiucchi, Giuliani, \& Poli, 2018b). It can be the proportion of male (female) owners. Alternatively, it can be the proportion of equity held by male (female) owners. Although they are conceptually different and each of them, as well as together, deserves to be observed, they are highly correlated within the sample of companies used and, more in general, within Italian SMEs (Chiucchi, Giuliani, \& Poli, 2018a; Chiucchi, Giuliani, \& Poli, 2018b). If both of them were included in the same regression equation, due to their high correlation, collinearity problems would emerge. Keeping them separate, instead, the results would be qualitatively the same. For this reason, the results shown below relate only to a way of considering $\mathrm{p}$ and precisely to the first of the two discussed above (SHANNON1).

When the gender diversity in board of directors is considered, $\mathrm{p}$ is understood and calculated as the proportion of male (female) members (SHANNON2).

The diversity index of Shannon can take values ranging from 0 (minimum level of gender diversity, corresponding to the case in which all owners or members of the board of directors are of the same genre) to 
0.69 (maximum level of gender diversity, corresponding to the case in which the owners or members of board of directors of each genre have the same proportion). If $\mathrm{p}_{\text {male(female) }}=0$, the corresponding logarithm is not defined. In this case, conventionally, the diversity index of Shannon takes the value of 0 .

The investigation has also been conducted using the diversity index of Blau (1977). However, the results are not reported because they are qualitatively the same as those obtained using the other diversity index.

\subsection{Control Variables}

Previous studies (Chen, Cheng, \& Hwang, 2005; Firer \& Mitchell Williams, 2003; Ho \& Williams, 2003; Pew Tan, Plowman, \& Hancock, 2007; Shahveisi, Khairollahi, \& Alipour, 2016) have shown that companies' size, indebtedness and economic sector can affect their financial and IC performance. Consistently, measures of these companies' characteristics are included in the model as control variables. Specifically, the variable SIZE (the natural logarithm of total assets at the end of the year of reference) has been included to control for companies' size. The variable LEV (the ratio between total liabilities and total assets at the end of the year of reference) has been included to control for companies' indebtedness. A set of forty-six dummy variables (shortly, SECTOR) has been included to control for companies' economic sector. The classification by sector has been made taking into account the first two digits of the economic sector code adopted in Italy (ATECO 2007).

\subsection{Testing Methodology}

As written at the beginning of this section, to test research hypotheses, the Baron and Kenny's (1986) testing mediation model has been adopted. It is based on the estimation of three regression equations.

In the first (Model 1), it is regressed the mediator $\left(\mathrm{VAIC}^{\mathrm{TM}}\right)$ on the independent variable (SHANNON1 or SHANNON2):

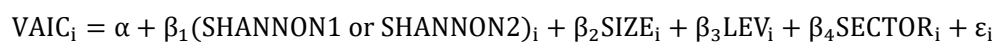

In the second (Model 2), it is regressed the dependent variable (ROE or ROA) on the independent one (SHANNON1 or SHANNON2):

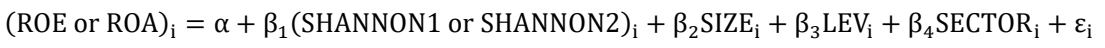

In the third (Model 3), it is regressed the dependent variable (ROE or ROA) on the independent one (SHANNON1 or SHANNON2) and the mediator $\left(\mathrm{VAIC}^{\mathrm{TM}}\right)$ :

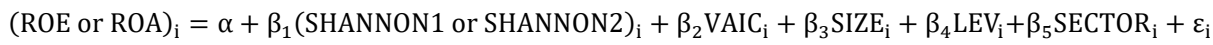

All the variables are calculated as written above.

In order to verify the robustness of the previous testing methodology, the mediation effect, namely the indirect effect of gender diversity in ownership or board of directors on financial performance via IC performance, is also tested through the "product-of-coefficients approach", using the bootstrapping method suggested by Preacher and Hayes (2004).

\subsection{Sample Selection and Data}

The analysis has been carried out on Italian private companies. The sample of companies and all the relative and necessary data have been extracted from the AIDA database. It is the largest database of economic and financial data relating to Italian private companies.

The companies have been selected according to the criteria that follow:

- limited liability company;

- private (unlisted) company;

- active company;

- $\quad$ small and medium company as defined by European legislation;

- $\quad$ financial statements prepared according to Italian legislation and GAAP;

- companies required to prepare the financial statements in the ordinary form; this occurs when, for two 
consecutive fiscal years, companies exceed two of the following three parameters: total assets $€ 8,800,000$; total revenues $€ 4,400,000$; average number of employees 50 ; the decision to use this selection criterion is because these companies are subject to greater accounting controls that ensure a better quality of the financial statements;

- $\quad$ total shareholder equity $>0$;

- $\quad$ value added $>0$;

- $\quad$ total cost for employees $>0$;

- $\quad$ ownership structure composed of only individuals.

6,870 companies have met the above selection criteria. 764 companies have been subtracted because they have incomplete or invalid data (338 companies), they have outlier value of the mediator or dependent variable $\left(<1^{\text {st }}\right.$ percentile or $>99^{\text {th }}$ percentile) (321 companies), or the economic sector they belong to has appeared under-represented ( $<10$ companies) (105 companies). 6,106 companies have been used to carry out the analysis.

\section{Results}

Table 1 shows the main descriptive statistics referring to the companies of the sample.

Table 1. Sample companies

\begin{tabular}{|c|c|c|c|c|c|c|c|}
\hline & Mean & & Standard deviation & Median & & & \\
\hline ROE & & 0.10 & 0.14 & & 0.07 & -0.77 & 0.71 \\
\hline ROA & & 0.03 & 0.04 & & 0.02 & -0.09 & 0.21 \\
\hline $\mathrm{VAIC}^{\mathrm{TM}}$ & & 2.50 & 1.16 & & 2.16 & 0.44 & 10.46 \\
\hline SHANNON1 & & 0.40 & 0.32 & & 0.56 & 0.00 & 0.69 \\
\hline SHANNON2 & & 0.22 & 0.30 & & 0.00 & 0.00 & 0.69 \\
\hline SIZE & & 16.40 & 0.60 & & 16.36 & 13.74 & 20.31 \\
\hline LEV & & 0.67 & 0.20 & & 0.72 & 0.02 & 1.00 \\
\hline
\end{tabular}

Gender diversity in ownership is restricted. A SHANNON1 median of about 0.56 means that the proportion of the owners of a gender category ranges between $0 \%$ and $25 \%$ of all owners in $50 \%$ of the companies of the sample. The companies that have the same number of male or female owners are about $26 \%$.

The gender diversity in board of directors is much more restricted. A SHANNON2 median of 0.00 means that the proportion of the directors of a gender category is $0 \%$ of all directors in $50 \%$ of the companies of the sample. The companies that have the same number of male or female members of board of directors are about $10 \%$.

Table 2 shows the correlation matrix.

Table 2. Correlation matrix

\begin{tabular}{|c|c|c|c|c|c|c|}
\hline & ROA & $\mathrm{VAIC}^{\mathrm{TM}}$ & SHANNON1 & SHANNON2 & SIZE & LEV \\
\hline ROE & $0.7018 * *$ & $0.3340 * *$ & $-0.0470 * *$ & $-0.0376 * *$ & $-0.0716^{* *}$ & 0.0087 \\
\hline ROA & & $0.4681 * *$ & -0.0180 & $0.0257^{* *}$ & 0.0117 & $-0.4571 * *$ \\
\hline VAIC $^{\mathrm{TM}}$ & & & $-0.0428^{* *}$ & $-0.0575^{* *}$ & $0.0933^{* *}$ & $-0.2231^{* *}$ \\
\hline SHANNON1 & & & & $0.3413 * *$ & $0.0611 * *$ & $-0.0742 * *$ \\
\hline SHANNON2 & & & & & $0.0744 * *$ & $-0.1192 * *$ \\
\hline SIZE & & & & & & $-0.1611 * *$ \\
\hline
\end{tabular}

Note. ${ }^{* *}$ indicates significance at $5 \%$.

Correlation indexes between explanatory (independent and control) variables may suggest the existence of collinearity problems that would lead to misleading results of OLS models. This may happen when correlation indexes exceed certain thresholds. Table 2 shows that the correlation index between explanatory variables are never so high that collinearity problems are suspected. The analysis of the Variance Inflation Factors has 
confirmed the inexistence of collinearity problems.

Table 3 shows the results of regression models when the independent variable is gender diversity in ownership (SHANNON1).

It shows that:

- the independent variable (SHANNON1) affects the mediator (VAIC ${ }^{\mathrm{TM}}$ ) in a negative and statistically significant way (Model 1);

- the independent variable (SHANNON1) also affects the dependent variable (both ROE and ROA) in a negative and statistically significant way (Model 2);

- the mediator $\left(\mathrm{VAIC}^{\mathrm{TM}}\right)$ affects the dependent variable (both ROE and ROA) in a positive and statistically significant way (Model 3);

- the effect (in absolute value) of the independent variable (SHANNON1) on the dependent variable (both $\mathrm{ROE}$ and ROA) in the regression model that controls for the mediator $\left(\mathrm{VAIC}^{\mathrm{TM}}\right)$ (Model 3) is lesser than in the regression model that does not control for the mediator $\left(\mathrm{VAIC}^{\mathrm{TM}}\right)$ (Model 2).

Thus, the research hypothesis is confirmed: the IC performance mediates the effect of gender diversity in ownership on financial performance. The mediation effect is partial since the independent variable (SHANNON1) impacts on the dependent variable (both ROE and ROA) in a statistically significant way in the regression model that controls for the mediator (VAIC ${ }^{\mathrm{TM}}$ ) (Model 3) (Baron and Kenny, 1986).

The "product-of-coefficients approach" suggested by Preacher and Hayes (2004) confirms the existence of the mediation effects. When the dependent variable is ROE, the regression coefficient of the indirect (mediation) effect is -0.0096 , and the related standard error is 0.0021 . The corresponding confidence interval ranges from -0.0137 to -0.0056 . When the dependent variable is ROA, the regression coefficient of the indirect (mediation) effect is -0.0031 , and the related standard error is 0.0007 . The corresponding confidence interval ranges from -0.0044 to -0.0019 .

Table 3. Results of regression models (independent variable: SHANNON1)

\begin{tabular}{|c|c|c|c|c|c|}
\hline \multirow[t]{3}{*}{ Variables } & \multicolumn{5}{|c|}{$\begin{array}{c}\text { Coefficients } \\
\text { (Heteroscedasticity-robust standard errors }- \text { variant } \mathrm{HC} 1)\end{array}$} \\
\hline & $\mathrm{DV}=\mathrm{VAIC}$ & $\mathrm{DV}=\mathrm{ROE}$ & $\mathrm{DV}=\mathrm{ROE}$ & $\mathrm{DV}=\mathrm{ROA}$ & $\mathrm{DV}=\mathrm{ROA}$ \\
\hline & Model 1 & Model 2 & Model 3 & Model 2 & Model 3 \\
\hline Constant & $\begin{array}{l}0.9206 * * \\
(0.4436)\end{array}$ & $\begin{array}{c}0.3563 * * * \\
(0.0535)\end{array}$ & $\begin{array}{c}0.3140 * * * \\
(0.0517)\end{array}$ & $\begin{array}{c}0.1614 * * * \\
(0.0138)\end{array}$ & $\begin{array}{c}0.1476 * * * \\
(0.0130)\end{array}$ \\
\hline SHANNON1 & $\begin{array}{c}-0.2092 * * * \\
(0.0448)\end{array}$ & $\begin{array}{c}-0.0194 * * * \\
(0.0057)\end{array}$ & $\begin{array}{l}-0.0098^{*} \\
(0.0054)\end{array}$ & $\begin{array}{c}-0.0066^{* * *} \\
(0.0015)\end{array}$ & $\begin{array}{c}-0.0034 * * \\
(0.0013)\end{array}$ \\
\hline VAIC $^{\mathrm{TM}}$ & & & $\begin{array}{c}0.0459 * * * \\
(0.0024)\end{array}$ & & $\begin{array}{c}0.0150^{* * *} \\
(0.0007)\end{array}$ \\
\hline SIZE & $\begin{array}{c}0.1863 * * * \\
(0.0263)\end{array}$ & $\begin{array}{c}-0.0148^{* * *} \\
(0.0032)\end{array}$ & $\begin{array}{c}-0.0234^{* * *} \\
(0.0031)\end{array}$ & $\begin{array}{c}-0.0039 * * * \\
(0.0008)\end{array}$ & $\begin{array}{c}-0.0067^{* * *} \\
(0.0008)\end{array}$ \\
\hline LEV & $\begin{array}{c}-1.2863 * * * \\
(0.0829)\end{array}$ & $\begin{array}{l}-0.0024 \\
(0.0087)\end{array}$ & $\begin{array}{c}0.0567 * * * \\
(0.0088)\end{array}$ & $\begin{array}{c}-0.0943 * * * \\
(0.0027)\end{array}$ & $\begin{array}{c}-0.0750^{* * *} \\
(0.0025)\end{array}$ \\
\hline SECTOR & INCLUDED & INCLUDED & INCLUDED & INCLUDED & INCLUDED \\
\hline $\mathrm{N}$ & 6,106 & 6,106 & 6,106 & 6,106 & 6,106 \\
\hline adjusted $\mathrm{R}^{2}$ & 0.1437 & 0.0223 & 0.1493 & 0.2302 & 0.3831 \\
\hline F & $17.7658 * * *$ & $3.4357 * * *$ & $10.7779 * * *$ & $29.4829 * * *$ & $42.6193 * * *$ \\
\hline
\end{tabular}

Note. $* * * * *$ and $*$ indicate significance at $1 \%, 5 \%$ and $10 \%$, respectively.

Table 4 shows the results of regression models when the independent variable is gender diversity in board of directors (SHANNON2).

It shows that:

- the independent variable (SHANNON2) affects the mediator (VAIC ${ }^{\mathrm{TM}}$ ) in a negative and statistically significant way (Model 1); 
- the independent variable (SHANNON2) also affects the dependent variable (both ROE and ROA) in a negative and statistically significant way (Model 2);

- the mediator (VAIC ${ }^{\mathrm{TM}}$ ) affects the dependent variable (both ROE and ROA) in a positive and statistically significant way (Model 3);

- the effect (in absolute value) of the independent variable (SHANNON1) on the dependent variable (both ROE and ROA) in the regression model that controls for the mediator (VAIC ${ }^{\mathrm{TM}}$ ) (Model 3) is lesser than in the regression model that does not control for the mediator $\left(\mathrm{VAIC}^{\mathrm{TM}}\right.$ ) (Model 2).

Thus, the research hypothesis is confirmed: the IC performance mediates the effect of gender diversity in board of directors on financial performance. The mediation effect is perfect since the independent variable (SHANNON2) does not impact on the dependent variable (both ROE and ROA) in a statistically significant way in the regression model that controls for the mediator (VAIC ${ }^{\mathrm{TM}}$ ) (Model 3) (Baron and Kenny, 1986).

The "product-of-coefficients approach" suggested by Preacher and Hayes (2004) confirms the existence of the mediation effects. When the dependent variable is ROE, the regression coefficient of the indirect (mediation) effect is -0.0143 , and the related standard error is 0.0021 . The corresponding confidence interval ranges from -0.0183 to -0.0102 . When the dependent variable is ROA, the regression coefficient of the indirect (mediation) effect is -0.0047 , and the related standard error is 0.0007 . The corresponding confidence interval ranges from -0.0060 to -0.0034 .

Table 4. Results of regression models (independent variable: SHANNON2)

\begin{tabular}{|c|c|c|c|c|c|}
\hline \multirow[t]{3}{*}{ Variables } & \multicolumn{5}{|c|}{$\begin{array}{l}\text { Coefficients } \\
\text { (Heteroscedasticity-robust standard errors - variant } \mathrm{HC} 1 \text { ) }\end{array}$} \\
\hline & $\mathrm{DV}=\mathrm{VAIC}$ & $\mathrm{DV}=\mathrm{ROE}$ & $\mathrm{DV}=\mathrm{ROE}$ & $\mathrm{DV}=\mathrm{ROA}$ & $\mathrm{DV}=\mathrm{ROA}$ \\
\hline & Model 1 & Model 2 & Model 3 & Model 2 & Model 3 \\
\hline \multirow[t]{2}{*}{ Constant } & $0.8735^{* *}$ & $0.3534 * * *$ & $0.3132 * * *$ & $0.1606^{* * *}$ & $0.1475 * * *$ \\
\hline & $(0.4430)$ & $(0.0536)$ & $(0.0518)$ & $(0.0138)$ & $(0.0130)$ \\
\hline \multirow[t]{2}{*}{ SHANNON2 } & $-0.3100 * * *$ & $-0.0163 * * *$ & -0.0020 & $-0.0039 * *$ & 0.0007 \\
\hline & $(0.0442)$ & $(0.0057)$ & $(0.0053)$ & $(0.0016)$ & $(0.0014)$ \\
\hline \multirow[t]{2}{*}{ VAICTM } & & & $0.0460 * * *$ & & $0.0151^{* * *}$ \\
\hline & & & $(0.0024)$ & & $(0.0007)$ \\
\hline \multirow[t]{2}{*}{ SIZE } & $0.1892 * * *$ & $-0.0149 * * *$ & $-0.0236^{* * *}$ & $-0.0040 * * *$ & $-0.0068 * * *$ \\
\hline & $(0.0264)$ & $(0.0032)$ & $(0.0032)$ & $(0.0008)$ & $(0.0008)$ \\
\hline \multirow[t]{2}{*}{ LEV } & $-1.3101 * * *$ & -0.0029 & $0.0574 * * *$ & $-0.0943 * * *$ & $-0.0745 * * *$ \\
\hline & $(0.0832)$ & $(0.0087)$ & $(0.0088)$ & $(0.0028)$ & $(0.0025)$ \\
\hline SECTOR & INCLUDED & INCLUDED & INCLUDED & INCLUDED & INCLUDED \\
\hline $\mathrm{N}$ & 6,106 & 6,106 & 6,106 & 6,106 & 6,106 \\
\hline adjusted R2 & 0.1470 & 0.0216 & 0.1488 & 0.2286 & 0.3825 \\
\hline $\mathrm{F}$ & $17.4880^{* * *}$ & $3.3412 * * *$ & $10.7394 * * *$ & $29.1411 * * *$ & $42.4270 * * *$ \\
\hline
\end{tabular}

Note. $* * *, * *$ and $*$ indicate significance at $1 \%, 5 \%$ and $10 \%$, respectively.

\section{Conclusions}

This paper aimed to investigate if IC performance can be considered as a mediator in the relationship between gender diversity and financial performance. In order to achieve this aim, a sample of Italian SMEs has been tested adopting the Baron and Kenny's (1986) mediation model.

The study has three main findings that correspond to as many contributions to literature.

The first finding concerns the relationship between IC performance and financial performance. About this, the study has shown that the former positively impacts on the latter, confirming the findings of the many previous theoretical and empirical studies that have investigated this relationship (Cheng, Lin, Hsiao, \& Lin, 2010; Clarke, Seng, \& Whiting, 2011; Gan \& Saleh, 2008; Graaf, 2013; Gruian, 2011; Makki \& Lodhi, 2008; María Díez, Lizet Ochoa, Begona Prieto, \& Santidrián, 2010; Mojtahedi, 2013; Nimtrakoon, 2015; Ozturk \& Demirgunes, 2007; Pew Tan, Plowman, \& Hancock, 2007; Pitelli Britto, Monetti, \& da Rocha Lima Jr, 2014; Pulic, 2000a; Singh \& Narwal, 2015; Zeghal \& Maaloul, 2010). This finding enriches the extant studies as it offers insights about the existence of a positive relationship between IC performance and financial performance also in Italian 
SMEs, a context not yet explored. In addition, this result, as well as the following ones, contributes to the stream of studies regarding IC performance in SMEs (Agostini, Nosella, \& Filippini, 2017; Khalique, Bontis, Shaari, Yaacob, \& Ngah, 2018).

The second finding concerns the relationship between gender diversity and IC performance. About this, the study has shown that the former, i.e. the gender diversity of both ownership and board of directors, has a negative impact on the latter. Concerning gender diversity in ownership, the finding supports the argument pushed forward by Chiucchi, Giuliani, and Poli (2018a; 2018b). Concerning gender diversity in board of directors, the finding allows extending the knowledge of the relationship between gender diversity and IC performance as it is the first one that is focused on this issue with reference to board of directors in Italian SMEs. These findings support the idea of the validity of the similarity-attraction paradigm also within the IC field (Horwitz, 2005; Horwitz \& Horwitz, 2007).

The third finding concerns the relationship between gender diversity and financial performance and the role IC performance plays in this relationship. About this, the study has shown that gender diversity in ownership negatively impacts on financial performance, directly and indirectly, and that gender diversity in board of directors negatively impacts on financial performance, only indirectly. The indirect effects are due to the negative impact of gender diversity, both in ownership and in board of directors, on IC performance. In fact, IC performance plays the role of mediator in the relationship between gender diversity and financial performance. The mediating effect is partial with reference to gender diversity in ownership. It is perfect regarding gender diversity in board of directors. This study contributes to the extant literature about the relationships between gender diversity, IC performance and financial performance by offering a systemic analysis of these three items that tend to be investigated separately. Besides, this study contributes to the investigations about the "mediator" or "moderator" role of IC performance.

This paper also has practical implications. It suggests that in order to improve IC performance and financial performance, it is important to consider also an adequate corporate governance setting. This paper also provides evidence useful for policymakers for defining policy able to support the development of IC and promoting gender diversity in organizational settings.

The limitations of this study are as follows. A first limit concerns the methodology. According to Baron and Kenny (1986: 1177), "[t]he use of multiple regression to estimate a mediational model requires [...] that the dependent variable not cause the mediator". There are previous studies that have found that financial performance can impact on IC performance. Future studies may overcome the detected limit using different models of analysis. A second limitation of the study concerns the fact that it focuses on Italian SMEs. This may pose a potential challenge in terms of generalizability, even though the private firm setting is rather similar in many countries. Future studies could overcome this limit extending the investigation to SMEs of other countries.

\section{References}

Abor, J., \& Biekpe, N. (2007). Corporate governance, ownership structure and performance of SMEs in Ghana: implications for financing opportunities. Corporate Governance: The International Journal of Business in Society, 7(3), 288-300. https://doi.org/10.1108/14720700710756562

Agostini, L., Nosella, A., \& Filippini, R. (2017). Does intellectual capital allow improving innovation performance? A quantitative analysis in the SME context. Journal of Intellectual Capital, 18(2), 400-418. https://doi.org/10.1108/JIC-05-2016-0056

Al-Musali, M. A. K. M., \& Ismail, K. N. I. K. (2015). Board diversity and intellectual capital performance: The moderating role of the effectiveness of board meetings. Accounting Research Journal, 28(3), 268-283. https://doi.org/10.1108/ARJ-01-2014-0006

Ali, M., Kulik, C. T., \& Metz, I. (2011). The gender diversity-performance relationship in services and manufacturing organizations. The International Journal of Human Resource Management, 22(7), 1464-1485. https://doi.org/10.1080/09585192.2011.561961

Andreoni, J., \& Vesterlund, L. (2001). Which is the fair sex? Gender differences in altruism. The Quarterly Journal of Economics, 116(1), 293-312. https://doi.org/10.1162/003355301556419

Arenas, T., \& Lavanderos, L. (2008). Intellectual capital: Object or process? Journal of Intellectual Capital, 9(1), 77-85. https://doi.org/10.1108/14691930810845812

Arosa, B., Iturralde, T., \& Maseda, A. (2010). Ownership structure and firm performance in non-listed firms: Evidence from Spain. Journal of Family Business Strategy, 1(2), 88-96. 
https://doi.org/10.1016/j.jfbs.2010.03.001

Baron, R. M., \& Kenny, D. A. (1986). The moderator-mediator variable distinction in social psychological research: Conceptual, strategic, and statistical considerations. Journal of Personality and Social Psychology, 51(6), 1173. http://dx.doi.org/10.1037/0022-3514.51.6.1173

Bear, S., Rahman, N., \& Post, C. (2010). The impact of board diversity and gender composition on corporate social responsibility and firm reputation. Journal of Business Ethics, 97(2), 207-221. https://doi.org/10.1007/s10551-010-0505-2

Bellucci, A., Borisov, A., \& Zazzaro, A. (2010). Does gender matter in bank-firm relationships? Evidence from small business lending. Journal of Banking \& Finance, 34(12), 2968-2984. https://doi.org/10.1016/j.jbankfin.2010.07.008

Betz, M., O'Connell, L., \& Shepard, J. M. (1989). Gender differences in proclivity for unethical behavior. Journal of Business Ethics, 8(5), 321-324. https://doi.org/10.1007/BF00381722

Blau, P. M. (1977). Inequality and heterogeneity: A primitive theory of social structure (Vol. 7). New York: Free Press.

Bontis, N., Bart, C. K., Nazari, J. A., \& Herremans, I. M. (2007). Extended VAIC model: measuring intellectual capital components. Journal of Intellectual Capital, 8(4), 595-609. https://doi.org/10.1108/14691930710830774

Brammer, S., Millington, A., \& Pavelin, S. (2007). Gender and ethnic diversity among UK corporate boards. Corporate Governance: An International Review, 15(2), 393-403. https://doi.org/10.1111/j.1467-8683.2007.00569.x

Byrnes, J. P., Miller, D. C., \& Schafer, W. D. (1999). Gender differences in risk taking: A meta-analysis. American Psychological Association, 125(3), 367-383 https://doi.org/10.1037//0033-2909.125.3.367

Campbell, K., \& Mínguez-Vera, A. (2008). Gender diversity in the boardroom and firm financial performance. Journal of Business Ethics, 83(3), 435-451. https://doi.org/10.1007/s10551-007-9630-y

Carter, D. A., D'Souza, F., Simkins, B. J., \& Simpson, W. G. (2010). The gender and ethnic diversity of US boards and board committees and firm financial performance. Corporate Governance: An International Review, 18(5), 396-414. https://doi.org/10.1111/j.1467-8683.2010.00809.x

Carter, S., Anderson, S., \& Shaw, E. (2000). Women's business ownership: A review of the academic, popular and internet literature with a UK policy focus. ARPENT: Annual Review of Progress in Entrepreneurship, $1(1), 66-157$.

Chaminade, C., \& Roberts, H. (2003). What it means is what it does: A comparative analysis of implementing intellectual capital in Norway and Spain. European Accounting Review, 12(4), 733-751. https://doi.org/10.1080/09638180310001628446

Chen, M. C., Cheng, S. J., \& Hwang, Y. (2005). An empirical investigation of the relationship between intellectual capital and firms' market value and financial performance. Journal of Intellectual Capital, 6(2), 159-176. https://doi.org/10.1108/14691930510592771

Cheng, M. Y., Lin, J. Y., Hsiao, T. Y., \& Lin, T. W. (2010). Invested resource, competitive intellectual capital, and corporate performance. Journal of Intellectual Capital, 11(4), 433-450. https://doi.org/10.1108/14691931011085623

Chiucchi, M. S., Giuliani, M., \& Marasca, S. (2016). The use of Intellectual Capital reports: The case of Italy. Electronic Journal of Knowledge Management, 14(4), 245-255.

Chiucchi, M. S., Giuliani, M., \& Poli, S. (2018a). Do ownership gender diversity and size matter? A focus on intellectual capital performance. International Journal of Business and Management, 13(2), 1-12. https://doi.org/10.5539/ijbm.v13n3p1

Chiucchi, M. S., Giuliani, M., \& Poli, S. (2018b). The relationship between intellectual capital performance and ownership gender diversity in small-sized Italian companies. In P. Paoloni \& R. Lombardi (Eds.), Gender Issues in Business and Economics - Selections from the 2017 Ipazia Workshop on Gender: Springer. https://doi.org/10.1007/978-3-319-65193-4_5

Chu, W. (2009). The influence of family ownership on SME performance: evidence from public firms in Taiwan. Small Business Economics, 33(3), 353-373. https://doi.org/10.1007/s11187-009-9178-6 
Clarke, M., Seng, D., \& Whiting, R. H. (2011). Intellectual capital and firm performance in Australia. Journal of Intellectual Capital, 12(4), 505-530. https://doi.org/10.1108/14691931111181706

Cohen, S., \& Kaimenakis, N. (2007). Intellectual capital and corporate performance in knowledge-intensive SMEs. The Learning Organization, 14(3), 241-262. https://doi.org/10.1108/09696470710739417

Daily, C. M., \& Dollinger, M. J. (1992). An empirical examination of ownership structure in family and professionally managed firms. Family Business Review, 5(2), 117-136. https://doi.org/10.1111/j.1741-6248.1992.00117.x

Der Zahn, V., \& Mitchell, J. L. W. (2004). Association between gender and ethnic diversity on the boards of directors of publicly listed companies in South Africa and intellectual capital performance. Financial Reporting, Regulation and Governance Journal, 3(1), 30-64.

Dumay, J. (2012). Grand theories as barriers to using IC concepts. Journal of Intellectual Capital, 13(1), 4-15. https://doi.org/10.1108/14691931211196187

Dwyer, S., Richard, O. C., \& Chadwick, K. (2003). Gender diversity in management and firm performance: The influence of growth orientation and organizational culture. Journal of Business Research, 56(12), 1009-1019. https://doi.org/10.1016/S0148-2963(01)00329-0

Earley, C. P., \& Mosakowski, E. (2000). Creating hybrid team cultures: An empirical test of transnational team functioning. Academy of Management Journal, 43(1), 26-49. https://doi.org/10.2307/1556384

Edvinsson, L., \& Malone, M. S. (Eds.). (1997). Intellectual Capital. New York: Harper Business.

El-Bannany, M. (2008). A study of determinants of intellectual capital performance in banks: the UK case. Journal of Intellectual Capital, 9(3), 487-498. https://doi.org/10.1108/14691930810892045

Elizabeth, C., \& Baines, S. (1998). Does gender affect business 'performance'? A study of microbusinesses in business services in the UK. Entrepreneurship \& Regional Development, 10(2), 117-135. https://doi.org/10.1080/08985629800000007

Fairlie, R. W., \& Robb, A. M. (2009). Gender differences in business performance: evidence from the Characteristics of Business Owners survey. Small Business Economics, 33(4), 375-395. https://doi.org/10.1007/s11187-009-9207-5

Firer, S., \& Mitchell Williams, S. (2003). Intellectual capital and traditional measures of corporate performance. Journal of Intellectual Capital, 4(3), 348-360. https://doi.org/10.1108/14691930310487806

Gan, K., \& Saleh, Z. (2008). Intellectual capital and corporate performance of technology-intensive companies: Malaysia evidence. Asian Journal of Business and Accounting, 1(1), 113-130.

Giuliani, M. (2013). Not all sunshine and roses: Discovering intellectual liabilities "in action". Journal of Intellectual Capital, 14(1), 127-144. https://doi.org/10.1108/14691931311289057

Giuliani, M. (2014). Accounting for intellectual capital: Investigating reliability. International Journal of Finance and Accounting, 3(6), 341-348.

Giuliani, M., Chiucchi, M. S., \& Marasca, S. (2016). A history of intellectual capital measurements: From production to consumption. Journal of Intellectual Capital, 17(3), 590-606. https://doi.org/10.1108/JIC-08-2015-0071

Giuliani, M., \& Marasca, S. (2011). Construction and valuation of intellectual capital: A case study. Journal of Intellectual Capital, 12(3), 377-391. https://doi.org/10.1108/14691931111154698

Graaf, J. (2013). Colouring the numbers-on the role of intellectual capital in financial reporting. Journal of Intellectual Capital, 14(3), 376-394. https://doi.org/10.1108/JIC-03-2013-0037

Gruian, C. M. (2011). The influence of intellectual capital on romanian companies' financial performance. Annales Universitatis Apulensis: Series Oeconomica, 13(2), 260-272.

Gry Agnete Alsos, P. U. H., Dr Elisabet Ljunggren, D., Agnete Alsos, G., Ljunggren, E., \& Hytti, U. (2013). Gender and innovation: state of the art and a research agenda. International Journal of Gender and Entrepreneurship, 5(3), 236-256. https://doi.org/10.1108/IJGE-06-2013-0049

Ho, C. A., \& Williams, S. M. (2003). International comparative analysis of the association between board structure and the efficiency of value added by a firm from its physical capital and intellectual capital resources. The International Journal of Accounting, 38(4), 465-491. https://doi.org/10.1016/j.intacc.2003.09.001 
Horwitz, S. K. (2005). The compositional impact of team diversity on performance: Theoretical considerations. Human Resource Development Review, 4(2), 219-245. https://doi.org/10.1177/1534484305275847

Horwitz, S. K., \& Horwitz, I. B. (2007). The effects of team diversity on team outcomes: A meta-analytic review of team demography. Journal of Management, 33(6), 987-1015. https://doi.org/10.1177/0149206307308587

Iazzolino, G., \& Laise, D. (2013). Value added intellectual coefficient (VAIC) A methodological and critical review. Journal of Intellectual Capital, 14(4), 547-563. https://doi.org/10.1108/JIC-12-2012-0107

Johnsen, G. J., \& McMahon, R. G. (2005). Owner-manager gender, financial performance and business growth amongst SMEs from Australia's business longitudinal survey. International Small Business Journal, 23(2), 115-142. https://doi.org/10.1177/0266242605050509

Kalev, A., Dobbin, F., \& Kelly, E. (2006). Best practices or best guesses? Assessing the efficacy of corporate affirmative action and diversity policies. American Sociological Review, 71(4), 589-617. https://doi.org/10.1177/000312240607100404

Kalleberg, A. L., \& Leicht, K. T. (1991). Gender and organizational performance: Determinants of small business survival and success. Academy of Management Journal, 34(1), 136-161. https://doi.org/10.2307/256305

Khalique, M., Bontis, N., Shaari, J. A. N. B., Yaacob, M. R., \& Ngah, R. (2018). Intellectual capital and organisational performance in Malaysian knowledge-intensive SMEs. International Journal of Learning and Intellectual Capital, 15(1), 20-36. https://doi.org/10.1504/IJLIC.2018.088345

Lau, D. C., \& Murnighan, J. K. (1998). Demographic diversity and faultlines: The compositional dynamics of organizational groups. Academy of Management Review, 23(2), 325-340. https://doi.org/10.5465/amr.1998.533229

Laure Humbert, A., \& Drew, E. (2010). Gender, entrepreneurship and motivational factors in an Irish context. International Journal of Gender and Entrepreneurship, 2(2), 173-196. https://doi.org/10.1108/17566261011051026

Li, J., Zhao, F., Chen, S., Jiang, W., Liu, T., \& Shi, S. (2016). Gender Diversity on Boards and Firms' Environmental Policy. Business Strategy and the Environment, 26(3), 306-315. https://doi.org/10.1002/bse.1918

Maditinos, D., Chatzoudes, D., Tsairidis, C., \& Theriou, G. (2011). The impact of intellectual capital on firms' market value and financial performance. Journal of Intellectual Capital, 12(1), 132-151. https://doi.org/10.1108/14691931111097944

Makki, M. A. M., \& Lodhi, S. A. (2008). Impact of intellectual capital efficiency on profitability (a case study of LSE25 companies). The Lahore Journal of Economics, 13(2), 81-98. https://doi.org/10.35536/lje.2008.v13.i2.a5

María Díez, J., Lizet Ochoa, M., Begona Prieto, M., \& Santidrián, A. (2010). Intellectual capital and value creation in Spanish firms. Journal of Intellectual Capital, 11(3), 348-367. https://doi.org/10.1108/14691931011064581

Mavridis, D. G. (2005). Intellectual capital performance determinants and globalization status of Greek listed firms. Journal of Intellectual Capital, 6(1), 127-140. https://doi.org/10.1108/14691930510574708

Meressa, H. A. (2016). Determinants of Intellectual Capital Performance: Empirical Evidence from Ethiopian Banks. Research Journal of Finance and Accounting, 7(13), 10-19.

Meritum. (2002). Proyecto Meritum. Guidelines for managing and reporting intangibles. Madrid.

Mojtahedi, P. (2013). Intellectual capital accounting and its impact on organizational financial performance: Evidence from Malaysian firms. Journal of Basic and Applied Scientific Research, 3(3), 840-845.

Mouritsen, J. (2009). Classification, measurement and the ontology of intellectual capital entities. Journal of Human Resource Costing \& Accounting, 13(2), 154-162. https://doi.org/10.1108/14013380910968665

Mouritsen, J., \& Larsen, H. T. (2005). The 2nd wave of knowledge management: The management control of knowledge resources through intellectual capital information. Management Accounting Research, 16(3), 371-394. https://doi.org/10.1016/j.mar.2005.06.006

Neergaard, H., Shaw, E., \& Carter, S. (2005). The impact of gender, social capital and networks on business ownership: a research agenda. International Journal of Entrepreneurial Behavior \& Research, 11(5), 


\section{8-357. https://doi.org/10.1108/13552550510614999}

Ngah, R., \& Ibrahim, A. R. (2009). The relationship of intellectual capital, innovation and organizational performance: A preliminary study in Malaysian SMEs. International Journal of Management Innovation Systems, 1(1), 1-13.

Nimtrakoon, S. (2015). The relationship between intellectual capital, firms' market value and financial performance: Empirical evidence from the ASEAN. Journal of Intellectual Capital, 16(3), 587-618. https://doi.org/10.1108/JIC-09-2014-0104

Orser, B. J., Riding, A. L., \& Manley, K. (2006). Women entrepreneurs and financial capital. Entrepreneurship Theory and Practice, 30(5), 643-665. https://doi.org/10.1111/j.1540-6520.2006.00140.x

Ozturk, M. B., \& Demirgunes, K. (2007). Determination of effect of intellectual capital on firm value via value added intellectual coefficient methodology: an empirical study on ISE-listed manufacturing firms. Istanbul Stock Exchange Review, 10(37), 59-78.

Pew Tan, H., Plowman, D., \& Hancock, P. (2007). Intellectual capital and financial returns of companies. Journal of Intellectual Capital, 8(1), 76-95. https://doi.org/10.1108/14691930710715079

Pitelli Britto, D., Monetti, E., \& da Rocha Lima Jr, J. (2014). Intellectual capital in tangible intensive firms: the case of Brazilian real estate companies. Journal of Intellectual Capital, 15(2), 333-348. https://doi.org/10.1108/JIC-10-2013-0108

Powell, M., \& Ansic, D. (1997). Gender differences in risk behaviour in financial decision-making: An experimental analysis. Journal of Economic Psychology, 18(6), 605-628. https://doi.org/10.1016/S0167-4870(97)00026-3

Preacher, K. J., \& Hayes, A. F. (2004). SPSS and SAS procedures for estimating indirect effects in simple mediation models. Behavior research methods, instruments, \& computers, 36(4), 717-731. https://doi.org/10.3758/BF03206553

Pulic, A. (2000a). MVA and VAIC Analysis of Randomly Selected Companies from FTSE 250. Retrieved 20 August 2017, from http://www.viac-on.net/downloads/ftse30.pdf

Pulic, A. (2000b). VAIC ${ }^{\text {TM}}$-an accounting tool for IC management. International Journal of Technology Management, 20(5-8), 702-714. https://doi.org/10.1504/IJTM.2000.002891

Rao, K., \& Tilt, C. (2016). Board composition and corporate social responsibility: The role of diversity, gender, strategy and decision making. Journal of Business Ethics, 138(2), 327-347. https://doi.org/10.1007/s10551-015-2613-5

Robinson, G., \& Dechant, K. (1997). Building a business case for diversity. The Academy of Management Executive, 11(3), 21-31. https://doi.org/10.5465/ame.1997.9709231661

Rogelberg, S. G., \& Rumery, S. M. (1996). Gender diversity, team decision quality, time on task, and interpersonal cohesion. Small Group Research, 27(1), 79-90. https://doi.org/10.1177/1046496496271004

Saeed, S., Rasid, S., \& Basiruddin, R. (2014). Impact of corporate governance on corporate performance through intellectual capital. In F. L. Gaol, S. Kadry, M. Taylor \& P. Shen Li (Eds.), Recent Trends in Social and Behaviour Sciences: Proceedings of the International Congress on Interdisciplinary Behaviour and Social Sciences 2013 (pp. 191-196). Boca Raton: CRC Press. https://doi.org/10.1201/b16658-35

Shahveisi, F., Khairollahi, F., \& Alipour, M. (2016). Does ownership structure matter for corporate intellectual capital performance? An empirical test in the Iranian context. Eurasian Business Review, 7(1), 67-91. https://doi.org/10.1007/s40821-016-0050-8

Shannon, C. E. (1948). A mathematical theory of communication. Bell System Technical Journal, 27(3), $379-423$. https://doi.org/10.1002/j.1538-7305.1948.tb01338.x

Singh, R. D., \& Narwal, K. P. (2015). Intellectual capital and its consequences on company performance: a study of Indian sectors. International Journal of Learning and Intellectual Capital, 12(3), 300-322. https://doi.org/10.1504/IJLIC.2015.070169

Smith, N., Smith, V., \& Verner, M. (2006). Do women in top management affect firm performance? A panel study of 2,500 Danish firms. International Journal of Productivity and Performance Management, 55(7), 569-593. https://doi.org/10.1108/17410400610702160

Ståhle, P., Ståhle, S., \& Aho, S. (2011). Value added intellectual coefficient (VAIC): a critical analysis. Journal of 


\section{Intellectual Capital, 12(4), 531-551. https://doi.org/10.1108/14691931111181715}

Steenkamp, N., \& Kashyap, V. (2010). Importance and contribution of intangible assets: SME managers' perceptions. Journal of Intellectual Capital, 11(3), 368-390. https://doi.org/10.1108/14691931011064590

Stewart, T. A. (1997). Intellectual Capital. New York, NY: Bantam Doubleday Dell Publishing Group.

Sveiby, K. E. (1997). The Intangible Assets Monitor. Journal of Human Resource Costing \& Accounting, 2(1), 73-97. https://doi.org/10.1108/eb029036

Swartz, N., \& Firer, S. (2005). Board structure and intellectual capital performance in South Africa. Meditari Accountancy Research, 13(2), 145-166. https://doi.org/10.1108/10222529200500017

Tajfel, H., \& Turner, J. C. (2004). The Social Identity Theory of Intergroup Behavior. In J. T. Jost \& J. Sidanius (Eds.), Key readings in social psychology. Political psychology: Key readings (pp. 276-293). New York, NY, US: Psychology Press. https://doi.org/10.4324/9780203505984-16

Watson, J., \& Robinson, S. (2003). Adjusting for risk in comparing the performances of male-and female-controlled SMEs. Journal of Business Venturing, 18(6), 773-788. https://doi.org/10.1016/S0883-9026(02)00128-3

Williams, K. Y., \& O’Reilly, C. A. (1998). Demography and diversity in organizations: A review of 40 years of research. Research in Organizational Behavior, 20, 79-140.

Zeghal, D., \& Maaloul, A. (2010). Analysing value added as an indicator of intellectual capital and its consequences on company performance. Journal of Intellectual Capital, 11(1), 39-60. https://doi.org/10.1108/14691931011013325

Zinkhan, G. M., \& Karande, K. W. (1991). Cultural and gender differences in risk-taking behavior among American and Spanish decision makers. The Journal of Social Psychology, 131(5), 741-742. https://doi.org/10.1080/00224545.1991.9924657

\section{Copyrights}

Copyright for this article is retained by the author(s), with first publication rights granted to the journal.

This is an open-access article distributed under the terms and conditions of the Creative Commons Attribution license (http://creativecommons.org/licenses/by/4.0/). 